\title{
The system of customs and tariff regulation of the EAEU in the context of globalization: problems, trends and prospects of development
}

\author{
Maxim Novikov ${ }^{1, *}$, and Stella Zemlyanskaya ${ }^{2}$ \\ ${ }^{1}$ Volgograd Institute of Management, Branch of the Russian Presidential Academy of National Economy and Public Administration, \\ Department of Economy and Finance, Gagarin Street, building 8, Volgograd, 400066, Russia \\ ${ }^{2}$ Volgograd State University, Institute of Economics and Finance, Chair of the Economic Theory, Regional and World Economics, \\ 100 Prospect Universitetsky, Volgograd, 400062, Russia
}

\begin{abstract}
.
Research background: Simplifying the system of foreign trade relations and providing advantages to individual States, allows you to increase the volume of foreign trade turnover and most effectively transform the structure of exports and imports of the country, taking into account its international specialization and competitive advantages. An integral component of the process of globalization is the strengthening of competition between national and foreign producers. In these conditions, it is important for the national economy to achieve a certain balance between protectionist measures and free trade instruments.

Purpose of the article: The purpose of this article is to summarize the theoretical and practical experience of using the tools of customs and tariff tools and develop recommendations to improve the efficiency of their application within the EAEU.

Methods: The research used methods of generalization, classification and comparative analysis of theoretical and methodological approaches to assessing the effectiveness of customs tariff instruments and their individual elements, methods of setting scientific hypotheses, grouping research depending on the conclusions and results obtained, and the possibility of using this experience to improve the system of customs and tariff regulation of the EAEU.

Findings \& Value added: As a result of the research, it was possible to identify the most acute problems of the customs and tariff regulation system of the EAEU, to identify their impact on the economy of the member States, to offer recommendations for improving the tools of customs and tariff regulation, and to assess the economic effect of the proposed recommendations.
\end{abstract}

Keywords: customs and tariff regulation; customs tariff; customs tariff escalation; tariff preferences; customs tariff policy

JEL Classification: $F 02 ; F 15 ; F 19 ; F 29$

\footnotetext{
${ }^{*}$ Corresponding author: novikovmv@yandex.ru
} 


\section{Introduction}

The system of international economic relations has undergone a radical transformation due to increased antagonism between the processes of globalization and regionalization over the past decade. Integration has become a modern reality of the world economic order. Its priority task is not to solve common socio-economic problems of the participating countries, but to use the integration association as a tool for economic isolation of specific states due to localizing economic relations within a limited number of states or a certain region. Another attribute of a new normality is the transfer of foreign policy contradictions to the economic area, i.e. trade wars are increasingly becoming the main means of resolving political confrontation between countries or their unions. If previously restrictive economic measures were used by the world community to stop or not resume international torts, now they are more and more actively used as agents of the political and economic will of individual hegemonic states [1].

Such actions result in an increase in political tension between individual countries, their unions, and regions as a whole. In this situation, it is important to maintain a certain balance of power, which can only be achieved by creating conditions for effective functioning and growth of production in the changed political and economic environment, on the one hand, and protecting the interests of national producers in foreign markets, on the other hand. It is impossible to solve such tasks without effective mechanisms for protecting economic interests of the EAEU member states, which can provide an adequate response to decentralized measures of economic coercion combining the tools of offensive and defensive protectionism of an extraterritorial nature [2, 3].

At present, protection of economic and political interests within the integration associations has become more relevant in Russian and foreign science due to the growing trends of globalization and regionalization. This is reflected in the works on the promotion of foreign trade activities through the use of selective instruments applied on a bilateral and multilateral basis between individual countries or integration associations. Of considerable interest is the issue of protecting the common market of integration association with the help of customs and tariff instruments and non-tariff restrictions $[4,5]$.

In this context, the main objective of this study is to identify the most effective directions of development of a customs-tariff regulation supranational system, that makes it possible to intensify the EAEU foreign trade considering qualitative changes of the commodity nomenclature, as well as measures protecting national interests of participating countries in terms of enhancing the processes of regional integration [6].

\section{Methods}

In the current moment in the domestic and foreign science the problem of the protection of national economic and political interests became even more important due to the increasing tendencies of globalization and regionalization. This problem is reflected in the papers devoted to the encouragement of foreign trade activity concerning the use of selective instruments which are used on multilateral base between specific countries or integration associations. It is worth mentioning that all these tools of the government regulation of foreign trade activity in domestic research are presented insufficiently.

In this respect the main goal of the present research is the identification of the most efficient strategies of the development of the national system of tariff regulation which allows encouraging the foreign trade taking into account qualitative changes of the foreign trade nomenclature of goods and also the measures ensuring the protection of national interest of Russia under the conditions of the acceleration of the processes of globalization and regionalization [7, 8].

The substantiation of modern tendencies of the process of foreign trade liberalization and its positive and negative impact on the economy of the Russian Federation and the economic systems of its economic partners in the Eurasian Economic Union is carried out by means of use of the methods of analysis and synthesis and also by means of the study of monographs. The statistical, economic and mathematical methods of research were used for the assessment of the foreign trade potential of the EAEU, quantitative and qualitative structure of the trade nomenclature of the foreign trade activity, the level of administrative and economic restrictions, tariff classification of the existing tariff barriers and also the level of the costs of the foreign trade liberalization.

The choice and the substantiation of the most efficient measures of tariff regulation of foreign trade activity and the measures of protection of the national market under the conditions of the foreign trade liberalization is achieved by means of the use of expert assessments and macroeconomic analysis. During the research the principle of the objectivity was used for a more complete characterization of the process of use of the measures of tariff regulation taking into account their positive and negative impact on the priority spheres of the national economy. The objective picture of consequences of foreign trade liberalization for the EAEU and the minimization of possible losses of domestic industries is ensured by the use of the consistency method. The development of efficient directions of tariff regulation of foreign trade taking into account the interests of the EAEU and the interests of its main foreign political and foreign trade partners is achieved due to the principle of alternativeness and the principle of actualization $[9,10]$. 


\section{Results}

The diverse nature of the tasks facing the foreign trade policy of the EAEU member states has increased the level of requirements for its consistency, validity, balance, efficiency, and flexibility necessary to adapt its directions to the present-day economic development. However, despite this, the analysis of the use of regulatory instruments revealed the discrepancy between this system and the attempts to diversify national production manifested in the absence of significant changes in the commodity structure of exports with a steady increase in budget revenues from the collection of customs duties.

These trends indicate the priority of fiscal function of instruments for foreign trade activities customs and tariff regulation, while at the same time there is a lack of stimulating and regulatory impact necessary to increase the economic potential of the EAEU member states, which is currently considered as a major problem in the functioning of this system of methods [11].

The main reasons for its occurrence include the following areas of concern in the field of customs and tariff regulation within the EAEU:

- non-compliance of customs duty rates with the economic environment of the EAEU common market and the world market,

- insufficient degree of customs tariff escalation,

- inefficient use of the system of tariff preferences.

The relevance of the first of these problems is defined by the value of customs duties in the system of state regulation and by the principle of suboptimality effect, which determines the existence of high requirements for objectivity and validity of changes in the level of tariff protection. The implementation of these requirements suggests that when you define or change the method of calculation and the size of customs duty rate many factors should be taken into account such as the level of competition for taxable item of goods, the prices of substitutes and complements of imported and domestic production, elasticity of supply and demand for the analyzed item, a list of the main suppliers of these products and many other indicators making it possible to assess the socio-economic and trade-political effects of changes of customs taxation level. This is precisely why the lack of a standard methodology for scientific justification of the use of this tool raise questions about the compliance of current customs duties with the real needs of production and the areas of economic development of the EAEU member states [12].

The next area of concern is the insufficient degree of tariff escalation manifested in the absence of significant differences between weighted average rates of customs duties on raw materials and finished products (Table 1).

Table 1. Dynamics of weighted average rate of common customs tariff of the EAEU in 2016-2018.

\begin{tabular}{|c|c|c|c|c|}
\hline \multirow{2}{*}{ Code } & Title & \multicolumn{2}{|c|}{ Weighted average rates, \% } \\
\cline { 2 - 5 } & & 2016 & 2017 & 2018 \\
\hline $01-24$ & Food products and agricultural raw materials (except \\
& textile) & 6.1 & 6.9 & 5.9 \\
\hline $25-27$ & Mineral products & 4.4 & 4.3 & 4.0 \\
\hline 27 & including fuel and energy products & 4.61 & 4.6 & 4.4 \\
\hline $28-40$ & Chemical industry products, rubber & 7.23 & 5.7 & 4.5 \\
\hline $41-43$ & Leather raw materials, furs and products made from & 12.2 & 11.7 & 11.7 \\
\hline $44-49$ & them & 6.1 & 5.7 & 5.6 \\
\hline $50-67$ & Textiles, textile products and footwear & 7.8 & 7.2 & 7.2 \\
\hline 71 & Precious stones, metals and products made from them & 11.6 & 9.5 & 8.8 \\
\hline $72-83$ & Metals and products made from them & 6.8 & 6.6 & 6.5 \\
\hline $84-90$ & Machinery, equipment and vehicles & 4.0 & 3.8 & 3.6 \\
\hline $67-70,91-97$ & Other goods & 10.5 & 9.5 & 9.0 \\
\hline
\end{tabular}

Source: own research

According to WTO statistics, the difference between the average level of customs taxation of these products specified in the current version of the common customs tariff of the EAEU is three times, while the degree of escalation of the US and EU customs tariffs exceeds thirty times. These data indicate that the principle of tariff escalation in developed countries is used more consistently, so that on the territory of these states, the system of customs and tariff instruments ensures full-scale implementation of protectionist and stimulating functions of state regulation of foreign trade.

Effective implementation of the principle of customs tariff escalation within the EAEU is hindered by the following areas of concern:

- Low degree of differentiation of customs duty rates; 
- The need for tariff protection of goods with a low degree of processing.

The first of presented problems, which complicates implementing the principle of tariff escalation is the limited number of values of customs duty rates set in the common customs tariff of the EAEU [13].

Currently, according to the EEC report, only 20 values of ad valorem customs duty are used in the common customs territory of the EAEU, which is more than 2 times lower than the differentiation of the US customs tariff, where the total number of interest rates includes 44 varieties. These data lead to a conclusion that the EAEU common customs tariff is characterized by weak degree of differentiation' which provides the inertia of this tool preventing the widening gap between the rates of customs duties on primary commodities, semi-finished and finished products and flexible implementation of regulatory functions within the EAEU [14].

Problems related to the need to set higher rates of customs duties on semi-finished products are caused by the lack of a full cycle of production of some finished products on the territory of the EAEU, attributable to the shortage of equipment and technologies necessary for their manufacture. This results in an increase in the number of enterprises engaged in the production of products with a low degree of processing. When implementing the principle of escalation and reducing customs duties on semi-finished products, most of these organizations cannot withstand increased competition in the domestic market due to the wear and tear of fixed assets and outdated technologies, access to the acquisition of which is significantly hindered by increasing the tariff rates for finished products. Consequentially, this situation leads to the fact that increasing the degree of escalation of customs tariff becomes difficult to implement without detriment to domestic production [15].

The next area of concern restraining the implementation of the regulatory function of the system of supranational regulation of foreign trade activities is the inefficient use of the Unified system of preferences of the EAEU (hereinafter referred to as the USP of the EAEU), the problems of functioning of which are reduced to a low degree of differentiation of preferential schemes, non-compliance with the stated and practical goals of using tariff preferences, lack of economic feasibility of their use, and a weakening role under conditions of foreign trade liberalization.

Currently, the USP of the EAEU involves two types of preferential schemes. The first one provides tariff preferences to developing countries in the amount of $75 \%$ of the current customs duty rate of the EAEU common customs tariff. The second one promotes the economic development of the least developed countries and entails the application of a zero rate of customs duty on goods originating from their territories. At the same time, it is impossible to change the preferential rate depending on the goods included in the preferential list of the USP of the EAEU. This implies that the use of this tool fails to consider the sensitivity of domestic products included on the preferential list to an increase in the supply of their imported analogues, which causes the problem of poorly detailed preferential schemes, so it is impossible to fully use the principle of tariff modulation [16].

A significant predominance of agricultural products that have not been subjected to deep processing on the list of preferential goods is the next problematic aspect of the USP of the EAEU. This indicates that the USP of the EAEU does not consider the level of competitiveness of individual industries of the beneficiary countries as well as the need to promote the development of preferential imports of deep processing products. These contradictions mean that formally aimed at promoting development the USP of the EAEU actually pursues functions other that incentive, which causes problems related to the discrepancy between the declared and practical purposes of applying preferences on the territory of the EAEU .

This problem affects not only the preferential list of goods, but also the list of beneficiary countries of the USP of EAEU, with two groups of countries - developing and least developed.

The list of least developed countries includes 48 states, the main beneficiaries of which are Bangladesh, Myanmar and Ethiopia, Malawi, Afghanistan, and Cambodia. The number of developing users of the USP of the EAEU includes 104 countries that are not classified by the World Bank as high-income countries. In this group, countries such as Brazil, China, Turkey, the Republic of Korea, Singapore, Argentina, Hong Kong, the United Arab Emirates and Saudi Arabia are beneficiaries of preferences, most of them significantly exceed the EAEU countries in terms of economic development. This circumstance indicates a problem related to the economic feasibility of using the USP of the EAEU in relation to individual states belonging to the group of developing countries whose economic level of development exceeds the granting states [17].

In addition to this contradiction, makeup of the list of member states using the USP of the EAEU is associated with the problem of preferential dualism, which means that several preferential schemes can be applied for a single beneficiary. The reason for this issue is that the list of countries that are granted preferences includes beneficiaries that already have other preferential channels for exporting goods to the common customs territory of the EAEU. Thus, the Republic of Serbia implements preferential access for its products to the EAEU market as a user of the USP of the EAEU, and at the same time receives tariff preferences within the free trade zone with the Russian Federation. A similar situation has developed with the Socialist Republic of Vietnam, which, on the one hand is a member of the free trade zone with the EAEU, and on the other, is a beneficiary of the USP of the EAEU. This provides a way for the beneficiary country to choose the most optimal preferential scheme for its goods, in other words to import them into the customs territory of the EAEU at the lowest possible customs duties [18].

The fiscal and protectionist limitations of the current system of customs and tariff regulation of the EAEU prevent creating harmonious conditions for the development of production and economic growth of states. At the same time, a complete lack of implementation of these functions entails no less adverse consequences for the economy, therefore 
improving the system of customs and tariff regulation should be consistent transition to the priority of regulating influence, which includes fiscal and defensive orientation in the use of the individual tools according to the principle of "targeted protectionism".

Targeted protectionism is expected to provide selective and point-wise input on the products, posing a threat to domestic production, which in turn necessitates the collection of statistical information, a comprehensive assessment of the impacts of change rate in the product group being studied and submitting appropriate proposals to the Department for customs-tariff and non-tariff regulation of the EEC.

Increasing of measures validity is essential at the stage of approving the need for making changes in the rates of customs duties; it directly depends on their degree of elaboration and results of the scientific assessments, the lack of a standard methodology of which is one of the areas of concern in the system of customs-tariff regulation.

The approval of mandatory procedure for scientific justification of each customs duty rate subject to adjustment, in accordance with the methodology of these recommendations, will enable resolving contradictions related to the insufficient degree of escalation of common customs tariff of the EAEU, and, in particular, the low differentiation of customs duty rates.

Taking into consideration the world practice of state regulation of foreign trade and specifics of building customs tariffs for developed countries, the most optimal way to increase the degree of escalation of the EAEU common customs tariff while implementing targeted protectionism is to establish megatariffs for imports of finished products, the production of which is most relevant for all EAEU member states [19].

To mitigate the negative consequences of the introduction of megatariffs in the common customs tariff of the EAEU, associated with an increase in the value of the weighted average customs duty rate, it is necessary to follow two main directions.

The first one is associated with an increase in the degree of tariff escalation by reducing the rates of customs duties on goods with a low degree of processing, which, given the problem of the need for tariff protection of production of semi-finished products, should be done by increasing the gap in the customs taxation of raw materials and semi-finished products.

The second direction is related to the participation of the EAEU members in the WTO's sectoral tariff initiatives, namely the "zero-on-zero" agreements, which involve the mutual abolition of customs duties on certain production sectors. Currently, the total number of these agreements includes 11 sectoral agreements and 14 projects aimed at establishing duty-free import of chemical goods, furniture, toys, steel, paper, medicines, timber, precious stones, refined spirits and other commodity groups, including agricultural equipment [20].

The latter commodity group, in view of the need for developing and modernizing import-substituting sectors of the economy, including the production of agricultural products classified as sensitive goods, is one of the most promising areas for improving the system of state regulation of foreign trade activities and an important measure to ensure the country's economic security.

In parallel with the establishment of new preferential schemes, it is necessary to modernize the current USP of the EAEU in accordance with the world practice and fundamental principles and criteria for building tariff preference systems in industrialized countries.

In order to implement the flexible regulatory and incentive impact of the USP of the EAEU, this system modernization should be based on the principle of tariff modulation, which has been successfully tested by state regulation of the EU and US foreign trade activities.

According to this principle, the list of preferential goods imported into the common customs territory of the EAEU should be revised taking into account the sensitivity criterion, i.e. the degree of competitiveness of domestic goods in relation to imported analogues that have access to the domestic market of member countries under preferential schemes. For each of the received groups, depending on the degree of sensitivity, a different rate of preferential duty should be set. Within the USP of the EAEU, the following implementation of the tariff modulation principle is possible, as shown in table 2 .

Table 2. Implementation of the principle of tariff modulation within the USP of the EAEU

\begin{tabular}{|l|c|c|}
\hline Degree of sensitivity of products & $\begin{array}{c}\text { Preferential rate (from the } \\
\text { most favoured nation regime } \\
\text { rate) }\end{array}$ & Preferential margin \\
\hline Very sensitive products & $75 \%$ & $25 \%$ \\
\hline Sensitive products & $60 \%$ & $40 \%$ \\
\hline Semi-sensitive products & $45 \%$ & $55 \%$ \\
\hline Insensitive products & $0 \%$ & $100 \%$ \\
\hline
\end{tabular}

Source: own research

Practical implementation of the above principle gives the EAEU more opportunities and freedom to carry out foreign trade maneuvers, considering changing political and economic realities and priorities in the field of ensuring the country's economic security, and also enables rationalizing the commodity structure of preferential imports, considering the economic interests of national producers [21]. 
Regardless of the modulation mechanisms for agricultural products, the principle of solidarity or "lion's share" should be applied, which implies setting a trigger level for partial withdrawal of states from the number of users of the system of preferences. Thus, when the established volume of imports of any product from the beneficiary country is reached, this state is deprived of the possibility of obtaining preferences for this product, which is subsequently subject to import duty corresponding to the MFN rate.

The next rule to be considered in the reform of the USP of the EAEU is the principle of gradation of countries by the level of economic development. Its essence is that countries that have reached a high level of development in general and have increased competitiveness in certain sectors no longer need or are not so badly in need of preferences, compared to less competitive countries.

The data shown in table 3 indicate that the EAEU exceeds by the number of beneficiary countries the states and integration associations with the level of economic development significantly higher than that of the EAEU member states. This situation seems illogical and requires a more detailed approach when including a country on the list of countries receiving tariff preferences within the EAEU.

Table 3. Country structure of beneficiary countries and unions under Generalized System of Preferences

\begin{tabular}{|c|c|c|c|}
\hline $\begin{array}{c}\text { Countries and integration } \\
\text { associations }\end{array}$ & Developing country & $\begin{array}{c}\text { Least developed } \\
\text { countries }\end{array}$ & Total \\
\hline EU & 32 & 48 & 80 \\
\hline Canada & 54 & 49 & 85 \\
\hline Norway & 51 & 34 & 122 \\
\hline USA & 79 & 43 & 130 \\
\hline Switzerland & 82 & 48 & 142 \\
\hline Japan & 95 & 47 & 152 \\
\hline
\end{tabular}

Source: own research

The gradation of countries according to their level of economic development will make it possible to solve problems related not only to the economically impractical application of tariff preferences, but also to non-compliance of the USP of the EAEU with declared goals of its application [22].

\section{Discussions}

The exclusion of dynamically developing countries from the list of countries - users of the system of preferences, whose income level exceeds these indicators for the EAEU members, will allow expanding the preferential list of goods towards products with a high degree of processing without the threat of damage to domestic production and aggravating competition between beneficiaries by transforming its conditions in favour of the least developed countries.

Improving the effectiveness of the USP of the EAEU also requires reviewing the existing tools of protective measures. Currently, trigger measures and tariff exemptions are the main tools for reducing negative effects of trade regime liberalization. Their main task within the preferential access to the national market is to reduce the negative consequences by gradually switching to a freer trade regime, allowing domestic industries to adapt to changing competitive conditions. The main drawback of these measures is that they are temporary. That is, at the end of the period stipulated in the specific agreement, they terminate. Thus, national industries remain virtually unprotected, which can cause significant damage to the economy of the EAEU members in context of deteriorating domestic and global market conditions [23].

In this situation, it is appropriate to apply the practice of a price range, which is a tariff regime under which it is possible to impose additional customs duties on preferential imports. The level of tariff protection determination is based on the minimum and base prices for the preferential product. When the base price is below the minimum level, additional customs duties are used to reduce the negative impact of the increasing volume of preferential imports and the costs of liberalization.

\section{Conclusion}

These problems require a deeper and more detailed study of the conditions for providing and using a particular customs tariff regulation tool. To strengthen the incentive and regulatory functions of customs duties, the principle of "targeted protectionism" and the principle of escalation should be used. In order to implement the protectionist function of customs duties more fully, it is necessary to ensure that national producers have access to participation in decision making on changes in customs duty rates by submitting an application indicating unfair competition in the domestic market. The degree of goods processing for granting tariff preferences in relation to them is considered as part of the implementation of tariff modulation principle. In order to ensure compliance with the potential and actual goals of customs preferences, it is necessary to exclude countries that are superior in their economic development to the EAEU 
countries from the list of beneficiaries, which includes legislating this procedure. To avoid preferential dualism countries should be allowed to use only one preferential scheme on a permanent basis.

Summing up the results in considering the problems and prospects for the development of customs and tariff regulation, it should be concluded that at present the importance of this system is gaining more and more relevance. The reasons lie in changing conditions and directions of economic development of the EAEU member states, which necessitate the modernization of production by attracting and developing modern technologies. This should be implemented through the regulatory functions of customs tariff system and rejection of primary right of fiscal functions, instead of governing one, carried out inseparable from the principle of targeted protectionism.

\section{References}

1. McKenzie, M. (2008). Climate change and the Generalized System of Preferences. Journal of International Economic Law, 11(3), 679-695.

2. Bartels, L., Haeberli, C. (2010). Binding Tariff Preferences for Developing Countries Under Article II Gatt. Journal of International Economic Law, 13(4), 969-995.

3. Emily, B., Shushanik, H. (2015). The US Generalised System of Preferences in Principle and Practice. The World Economy, 38(3), 399-424.

4. Irish, M. (2007). GSP Tariffs and Conditionality: A Comment on EC-Preferences. Journal of World Trade, 41 (4), 683-698.

5. Fisher, B. (2006). Preference Erosion, Government Revenues and Non-tariff Trade Barriers. The World Economy, 29(10), 1377-1393.

6. Portela, C., Orbie, J. (2014). Sanctions under the EU Generalised System of Preferences and foreign policy: coherence by accident? Contemporary Politics, 20(1), 63-76.

7. Witt, A.M. (2019). De-globalization: Theories, predictions, and opportunities for international business research. Journal of International Business Studies, 50(7), 1053-107.

8. Kano, L. (2018). Global value chain governance: A relational perspective. Journal of International Business Studies, 49(6), 684-705.

9. Benito, G.R., Petersen, B., Welch, L.S. (2019). The global value chain and internalization theory. Journal of International Business Studies, 50(7), 1414-1423.

10. Abdi, M., Aulakh, P.S. (2018). Internationalization and performance: Degree, duration, and scale of operations. Journal of International Business Studies, 49(7), 832-857.

11. Balandina, G., Ponomarev, Y., Sinelnikov-Murylev, S. (2020). Customs Administration in Russia: State-of-the-Art Procedures to Be Followed. Ekonomicheskaya politika, 15(1), 108-135.

12. UNCTAD (2019) Handbook on Duty-Free Quota-Free and Rules of Origin. New York and Geneva: United Nation.

13. Kaczmarski, M. (2017). Two Ways of Influence-building: The Eurasian Economic Union and the One Belt, One Road Initiative. Europe-Asia Studies, 69(7), 1027-1046.

14. Kiyanchuk, I. (2017). Influence of customs payments on the economic security of the country, problems and ways of overcoming. Baltic journal of economic studies, 3(3), 32-37.

15. Korf, D. (2017). Commodity Nomenclature and Classification of Goods for Customs Purposes in the Eurasian Economic Union. Pravo-zurnal Vysshei shkola ekonomiki, 3(1), 188-198.

16. Troshkina, T. (2017). Legal Regulation of Administering Customs Payments in EAEU States. Pravo-zurnal Vysshei shkola ekonomiki, 2, 237-252.

17. UNCTAD (2018) Generalized System of Preferences. Handbook on the Rules of Origin of the European Union. New York and Geneva: United Nation.

18. Manchin, M. (2006). Preference Utilisation and Tariff Reduction in EU Imports from ACP Countries. The World Economy, 29(9), 1243-1266.

19. Tarr, D.G. (2016). The Eurasian Economic Union of Russia, Belarus, Kazakhstan, Armenia, and the Kyrgyz Republic: Can It Succeed Where Its Predecessor Failed? Eastern European Economics, 54(1), 1-22.

20. UNCTAD (2019). Key Statistics and Trends in Trade Policy 2018. New York and Geneva: United Nation

21. Wardhaugh, B. (2013). GSP+ and Human Rights: Is the EU's Approach the Right One? Journal of International Economic Law, 16(4), 827-846.

22. UNCTAD (2017). Generalized System of Preferences. Handbook on the Scheme of the European Community. New York and Geneva: United Nation. 
23. Pirker, B. (2017) The Eurasian Economic Union and the European Union. Moving toward a Greater Understanding. Common Market Law Review, 54(3), 2017, 1578-1588. 